\title{
Chapter 2 \\ Policy Options of Over-Pumping Control in the NCP
}

Starting in the 1990s, China has been issuing regulations and policy rules related to groundwater management and pumping control on both national and provincial levels. These policies include the requirement of permits for well drilling, a well spacing policy, pumping quota management, water resources fee collection, setting of irrigation water prices, a water rights system, water markets, and more. Since the early 2010s, the central government increasingly paid attention to the groundwater depletion issue, leading to the deployment of the pilot program "Comprehensive Control of Groundwater Overdraft in North China Plain" in 2014. It coordinated efforts of several ministries and included innovative measures such as subsidies for fallowing of winter wheat and substitution of groundwater by surface water, especially for household and industry through the South-North Water Transfer Project. In Guantao County about $8 \mathrm{Mio}$. m3/yr of groundwater were saved through subsidized fallowing of winter wheat, while the import of surface water could be increased to almost 60 Mio m3/yr. However, continued funding of subsidies for fallowing is not guaranteed and the seemingly large imports of Yellow River water were used very inefficiently as the region lacks storage facilities to cope with water arriving off-season.

In China, policies are generally implemented through a top-down approach. Even though some policy pilots start on provincial or county level, eventually a national policy follows, upscaling the pilot experience to all relevant regions. This chapter summarizes China's recent national policies on groundwater management and assesses the efficiency of major measures for groundwater over-pumping control implemented through various pilots in Hebei province from 2014 to 2017. The chapter also highlights the most effective control measures adopted for further implementation in Beijing-Tianjin-Hebei (BTH) region from 2018 on and their implementation status. The governance structure of the water sector in China is introduced presenting the overall picture of groundwater management across different governmental bodies. 


\subsection{China's Groundwater Policies in Recent years}

China has issued regulations and policy rules related to groundwater management and pumping control on both national and provincial levels. These policies include the requirement of permits for well drilling, a well spacing policy, pumping quota management, water resources fee collection, setting of irrigation water prices, a water rights system, water markets, and more. A summary of these policy instruments is given below:

\subsubsection{Permit Policy for Well Drilling}

In the early 1990s, some provinces in northern China began to implement formal or informal well-drilling permit policies to control the drilling of tube wells and thus limit the utilization of groundwater. Although the policy has been implemented in certain provinces as early as the 1990s and is effective up to now, well permits were not included in the 2002 Water Law and no national water regulation has addressed this policy. Shen (2015) pointed out that well permits are inconsistent with the recent reform aiming at a reduction of administrative permits in China.

Based on a survey covering six provinces (Hebei, Henan, Shanxi, Shaanxi, Liaoning and Inner Mongolia) in North China, done by Prof. Jinxia Wang and her team at Peking University, in $199518 \%$ of villages had implemented a well-drilling permit policy. This share increased to $34 \%$ by 2004 and to $54 \%$ by 2015 (Wang et al. 2020a).

\subsubsection{Well-Spacing Policy}

In 2010, the Ministry of Water Resources issued technical guidance on tube well spacing in both rural and urban regions (MWR 2010). Depending on the distance, the groundwater withdrawal of one tube well will affect the groundwater availability at other tube wells in the same aquifer (Huang et al. 2013). Frija et al. (2015) stated that management tools such as appropriate well spacing are needed in areas with groundwater overexploitation and degradation. Therefore, a well-spacing policy to control farmers' tube well drilling is a crucial measure to ensure the supply reliability of groundwater irrigation. However, it is both time-consuming and technically demanding to provide scientific information for well spacing based on the local hydrogeological conditions. The implementation of this policy so far depends mainly on local people's experience (e.g. county officials, drilling teams, farmers). 


\subsubsection{Quota Management}

Water quota management was first introduced in China in the 2002 "Water Law". It only became a priority policy instrument after the "Three Red Lines" policies were issued by the central government in 2012 (State Council 2012). The central government required river basin management authorities and local water resources bureaus to determine water quotas for various water users at different administrative levels (i.e. river basin, province, city, county, irrigation district, and village). Under the water quota system, all water users should be issued withdrawal permits from upper-level water management authorities and their withdrawal rates (of both surface and groundwater) should not exceed the allocated quota. In recent years, the water quota concept has also been used in groundwater pumping control in the framework of the agricultural water pricing reform.

Despite central and local governments' efforts, implementation of water quota management remains difficult in rural areas. The main reasons are: First, water use differs by crops, farmers, and regions (according to soil and climate conditions) and it is difficult to calculate generally applicable water quota. Second, metering facilities for groundwater use in irrigation rarely exist. Third, the water rights system has not yet been established in all of China, and the relationship between water quota and this system remains unclear.

\subsubsection{Water Resources Fee and Tax}

(Kemper 2007) indicated that a water resources fee could provide incentives to use groundwater more efficiently. This is especially true if this fee is tied to the volume of groundwater used. Since the early 1980s, water resources fees have been introduced in certain provinces in northern China (e.g. Tianjin, Shanxi, Beijing) (Shen 2015). They are also included in the 2002 Water Law. In 2006 China's central government issued the "Regulations on the Management of Water Abstraction Permit and Collection of Water Resources Fee". The fee is collected by the water administration departments at the county level based on approved water abstraction permits. Where an abstraction permit is approved by river basin management organizations, the fee is collected by the relevant department of the province in which the water intake is located. It is based on the actual water abstraction volume and fee standards (Shen 2015).

Collecting groundwater resource fees in rural areas remains a major challenge for policymakers. Groundwater cost for irrigation includes pumping costs (including cost for drilling and equipment of tube wells, electricity cost or diesel fuel cost) but does not account for the scarcity value of groundwater. As (Yu et al. 2015) pointed out, the water price does not include the groundwater resource fee in most parts of rural China.

There is an ongoing transformation from a water resources fee to a water resources tax to enhance its potential role. In 2016 Hebei Province was selected as the pilot 
province for the fee to tax transformation. From 2017 the fee to tax reform has been expanded to 9 provinces including Beijing, Tianjin, Shanxi, Inner Mongolia, Henan, Shandong, Sichuan, Ningxia, and Shaanxi. No matter whether fee or tax, it is difficult to implement the policy in rural groundwater use. Farmers' low revenue from agricultural production and the lack of metering facilities for millions of irrigation pumping wells are both huge obstacles preventing the collection of a water resources tax from individual farmers.

\subsubsection{Irrigation Water Price Policy}

Over the past 40 years, the reform of China's irrigation water price policy has made some progress. After the first water fee regulation in 1985, surface water supply for irrigation was transformed from being fully subsidized to covering at least part of the cost by a supply fee. In 1992, price bureaus took over the management responsibilities for the irrigation fee from the Water Resources Bureaus, changing the nature of the fee from an administrative issue to a commodity issue. The irrigation fee further changed from a single to a two-part structure in the last two decades. The two parts include a basic fee charged by area and a volumetric fee charged by the amount of water used. In the last decade, the scarcity value of water resources was added as a component of the irrigation fee. In addition, from 2016 on, the central government began selecting regions to set up pilot projects to shift from water resources fees to water resources taxes. This might seem a change in name only. However, fees go to the water administration, possibly reducing their interest in water saving, while taxes go to the government tax office. The government also realized that irrigation price reform should be accompanied by improvement of irrigation facilities and institutional innovation (such as establishing WUAs).

Reform progress was mainly related to the price of surface water resources for irrigation, and not to the price of groundwater. In groundwater irrigation the major investors are farmers or village collectives. They mainly pay electricity or diesel fuel cost incurred for pumping water and so far, do not need to pay the resource fee. Collection of a groundwater resource fee is what the government expects from the reform of the irrigation water price. However, due to high implementation cost for collecting such a fee, until now this expectation cannot be fulfilled. Therefore, groundwater irrigation cost presently mainly consists of the energy cost (electricity or diesel fuel cost), cost for drilling and equipment of tube wells and eventually labor or service cost incurred during irrigation.

Due to poor measurement facilities and high implementation cost, it is hard to implement volumetric groundwater irrigation fees in the field. However, since most tube wells include electricity metering, and the major operation cost of a tube well is the electricity cost, it is common to collect groundwater irrigation fees based on electricity use. Charging groundwater irrigation fees according to electricity use can be treated as a proxy approach to a volumetric irrigation fee. A field survey by (Wang et al. 2020b) tracked 125 community tube wells managed by well managers. 
For this sample, the percentage of tube wells collecting a groundwater irrigation fee proportional to the electricity fee increased from $36 \%$ in 2001 to $78 \%$ in 2015 . In another approach, tube well managers collected groundwater irrigation fees by time of use of the well, which is another type of proxy approach to a volumetric irrigation fee. Over the past 15 years, the share of tube wells collecting groundwater irrigation fees by time of use slightly decreased from $25 \%$ in 2001 to $22 \%$ in 2015 . Before 2015 , some tube well managers also collected groundwater irrigation fees by area irrigated or by the amount of diesel fuel consumed.

\subsubsection{Water Rights System and Water Markets}

The Chinese government has been trying to set up a water rights system and allocate water through market mechanisms since the early 2000s (Calow et al. 2009). In theory, regulatory caps on total water use within a given region in a rational water rights system can lead to socially optimal allocation of water resources; thus, water can be used by those who value it most (Howe et al. 1986), (Debaere et al. 2014). Considering the potential benefit, the central government has been issuing regulations to promote the development of a water rights system over the last two decades. The first two important regulations were issued in 2005: "Some Opinions on Water Rights Transfer and Establishing a Framework of Water Rights System”. In 2014, the government launched formal pilot projects in seven provinces to further accelerate the development. These provinces included Ningxia, Jiangxi, Hubei, Inner Mongolia, Henan, Gansu, and Guangdong. To support the implementation of pilot projects and encourage water rights transactions among regions, sectors, and individual water users, the MWR issued the "Temporary Management Regulation on Water Rights' Transfer" in 2016. In the same year, the first national Transaction Institute of Water Rights was established in Beijing.

So far, only a few pilot projects of water rights transfer have been considered successful, especially those which trade among regions and industries. For example, there are two prominent water rights transfer projects (Speed 2009), (Moore 2015): between Dongyang and Yiwu in Zhejiang province, and between agricultural and industrial sectors in Inner Mongolia and Ningxia provinces. Though successful, they are mainly coordinated by local governments; water users in these regions have not been directly involved in the transactions. It should also be noted that while the transfer of water rights may increase water use efficiency it does not reduce the amount of water pumped from an aquifer and is therefore no solution to overpumping.

It is more difficult to establish a water rights system to promote rights transfer among irrigation water users in rural areas. At the irrigation district (ID) level, water rights have only been granted to farmers at a few select pilot sites, where water rights transactions among individual farmers are not always effective (Sun et al. 2016). Field surveys in China seldom found evidence of water rights' transfer among farmers. In fact, many farmers are unaware of their water use rights or the fact that they can 
be traded. A typical example for establishing a water rights system in rural areas is the institutional reform in Zhangye Prefecture in Gansu Province. Here, water rights have been granted to individual farmers in the form of water rights certificates. These certificates state the upper limit of the amount of water a household can buy, which is computed by area and crop irrigation quota. Even so, transactions involving water rights are rare in Zhangye. Importantly, because of poor implementation and high monitoring cost, water rights certificates do not have a sustainable function in reducing irrigation water demand. They only played a significant role in the early stages of the reform, where irrigation of wheat was reduced by $23 \%$ (before 2010). The survey (Sun et al. 2016) also found that farmers incurred practically no penalty for exceeding their water rights, which encourages them to use yet more water.

Despite progress made in establishing a water rights system and developing water markets, China still faces challenges in expanding reforms. There has also been a heated debate on the suitability of water markets in rural areas. The major issue is that initial water rights have not yet been allocated to various water users in most regions (Wang et al. 2017). It is impossible to develop water markets without a fully established water rights system. Recently, a water quota system has been suggested for allocating initial water rights to users. However, there is no clear agreement on the relationship between the water rights system and the water quota policy. In addition, the implementation of a water quota policy in rural areas has been slow because of the lack of metering facilities and the high cost involved in monitoring large numbers of small-holder farmers' wells. Therefore, some officials and scholars question its suitability for developing water markets in rural China, at least at the individual farmer level. If possible, it is better to encourage trade at the level of WUAs or IDs instead. (Lewis and Zheng 2018) noted that promoting water trade at the WUA level requires strong efforts to encourage farmers to participate in the activities of WUAs. Finally, the potential effects of water rights transfer on disadvantaged water users and on the environment also need to be seriously considered (Heaney et al. 2005; Johansson et al. 2002; Etchells et al. 2006).

\subsubsection{National Policy Focus: NCP's Groundwater Over-Pumping}

Regardless of all the policy rules and regulations published, implementation lags and groundwater over-pumping remains a major issue in the NCP. It has become a focus of national policy, appearing in many important state documents issued by the Central Committee of the Communist Party of China and the State Council. The most recent state documents include: 
1. "Decision of the Central Committee of the Communist Party of China and the State Council on Accelerating Water Conservancy Reform and Development" in 2011

This document demands that groundwater over-pumping should basically be stopped by 2020 .

2. "Opinions of the State Council on Implementing the Strictest Water Resources Management System” in 2012

This document calls for strict groundwater management and protection to reach a balance between groundwater exploitation and recharge.

3. "Decisions of the Central Committee of the Communist Party of China on Several Major Issues of Comprehensively Deepening Reform” in 2013

This document proposes several measures for groundwater management, including the establishment of pre-warning mechanisms based on the monitoring of resources and environmental carrying capacity and the implementation of restrictive measures for areas where water and soil resources are exploited beyond their capacities. The measures include adjustment of cropland area in regions with severe pollution and severe groundwater overexploitation, in order to rehabilitate arable land, rivers and lakes.

4. "Opinions of the Central Committee of the Communist Party of China and the State Council on Accelerating the Construction of Ecological Civilization" in 2015

The document states that the balance between groundwater extraction and recharge should gradually be reached by implementing groundwater protection and comprehensive management of the over-exploited areas characterized by groundwater depression cones.

5. "Outline of the 13th Five-Year Plan for the National Economic and Social Development of the People's Republic of China" in 2016

The document states that groundwater management should focus on areas of groundwater depression cones, exploring pilot measures of farmland rotation and fallowing mechanisms, developing scientific methods for the conjunctive use of surface water and groundwater and various types of unconventional water sources, strictly controlling groundwater exploitation, improving the national groundwater monitoring system, and comprehensively managing groundwater over-exploitation areas.

All these documents prove that groundwater depletion has been paid great attention to on the central government level since the beginning of the 2010s. This has resulted in the deployment of the pilot program "Comprehensive Control of Groundwater Overdraft in North China Plain" in Hebei Province in 2014, which has been supported by the Ministries of Finance, of Water Resources, of Agriculture and Rural Areas, and of Land Resources (now Natural Resources). The pilot program started in four prefectures (including Handan) in Hebei Province, covering 49 counties (including Guantao County in Handan Prefecture). 


\subsection{Groundwater Over-Pumping Control Measures in Hebei Province}

Different governmental departments in Hebei Province contributed different measures to reach the goal of groundwater overdraft control. From 2014 to 2017, Hebei Province yearly issued a report on "Integrated Pilot Planning for Governing Groundwater Overdraft". The measures used by various governmental departments are listed in Table 2.1. They cover all sectors involved, including Agriculture, Forestry and Water Resources, and can be categorized into two classes: demand side measures and supply side measures. Among the demand-side measures agriculture contributed mainly with subsidized fallowing of winter wheat, while forestry gave incentives to convert winter crops to water saving non-food crops such as trees. The water resources sector contributed by water saving irrigation technology and a water price reform system. The main activity of the water resources sector was, however, on the supply side, consisting of massive imports of surface water from the South (Yellow River and Yangtze River) to replace groundwater pumping and to increase aquifer recharge.

The effects and challenges of all new measures listed in Table 2.1 are assessed in the following sections.

\subsubsection{Seasonal Land Fallowing}

The Seasonal Land Fallowing Program (SLFP) was introduced as one of the important measures for groundwater overdraft control in Hebei. The main fallowing crop is winter wheat, which needs irrigation during its growth season from October through

Table 2.1 List of measures used in Hebei Province for groundwater overdraft control from 2014 to 2017

\begin{tabular}{l|l|l}
\hline Sector/Department & & Measures \\
\hline Agriculture & & $\begin{array}{l}\text { - Seasonal land fallowing (new) } \\
\text { Fertigation (traditional) }\end{array}$ \\
\hline Forestry & & $\begin{array}{l}\text { - Substitution of non-food crops for } \\
\text { grain crops (new) }\end{array}$ \\
\hline Water resources & Water conservation & $\begin{array}{l}\text { Replacing groundwater by surface } \\
\text { water (new) }\end{array}$ \\
& Agricultural water price reform & $\begin{array}{l}\text { Irrigation water saving technologies } \\
\text { (traditional) }\end{array}$ \\
\cline { 2 - 3 } & & $\begin{array}{l}\text { Buy-back of water rights (new) } \\
\text { Increase of prices and provision of } \\
\text { subsidies (new) } \\
\text { Tiered scheme of water fees (new) }\end{array}$ \\
\hline
\end{tabular}

Note New measures are the ones not used before 2014. Traditional measures have been used before 2014 
Table 2.2 Subsidized fallowed area and groundwater saved through subsidized fallowing in Handan and Guantao from 2014 to 2020

\begin{tabular}{l|l|l|l}
\hline Year & $\begin{array}{l}\text { Subsidized } \\
\text { fallowing area in } \\
\text { Handan }(\mathrm{mu})\end{array}$ & $\begin{array}{l}\text { Subsidized } \\
\text { fallowing area in } \\
\text { Guantao }(\mathrm{mu})\end{array}$ & $\begin{array}{l}\text { Reduction in groundwater pumping in } \\
\text { Guantao }\left(\mathrm{Mio} \mathrm{m}^{3}\right)\end{array}$ \\
\hline 2014 & 50,000 & 5,000 & $0.80-0.90$ \\
\hline 2015 & 73,500 & 15,000 & $2.40-2.70$ \\
\hline 2016 & 183,500 & 35,000 & $5.60-6.30$ \\
\hline 2017 & 226,656 & 37,000 & $5.92-6.66$ \\
\hline 2018 & 305,160 & 42,000 & $6.72-7.56$ \\
\hline 2019 & 395,400 & 62,000 & $9.92-11.16$ \\
\hline 2020 & 395,400 & 62,000 & $9.92-11.16$ \\
\hline
\end{tabular}

Note The range of reduction in groundwater pumping in Guantao is calculated with the irrigation norm for winter wheat as lower estimate $\left(160 \mathrm{~m}^{3} / \mathrm{mu} / \mathrm{year}\right)$ and the claimed water saving from the seasonal land fallowing program in Hebei Province as upper estimate $\left(180 \mathrm{~m}^{3} / \mathrm{mu} /\right.$ year $)$

May. Seasonal land fallowing has an immediate effect on groundwater table recovery. Water which is not pumped remains in the aquifer. The annual water saving claimed for fallowing winter wheat is up to $180 \mathrm{~m}^{3} / \mathrm{mu}(1 \mathrm{mu}=1 / 15 \mathrm{ha})$.

Seasonal land fallowing has been implemented in Handan Prefecture including Guantao County. The subsidized fallowed area in Guantao from 2014 on is listed in Table 2.2. The subsidized winter wheat fallowing in Guantao implies a reduction of groundwater pumping by up to $10 \mathrm{Mio} . \mathrm{m}^{3}$ per year under current funding. (Note that the net groundwater saving compared to winter wheat planting is only $80 \%$ of that figure when considering the irrigation backflow). It is a substantial contribution towards elimination of Guantao's groundwater gap. The fallowed area determined by remote sensing is virtually identical to the official figures (see Sect. 4.2.4).

Regardless of the success of seasonal land fallowing (mainly winter wheat fallowing) regarding groundwater saving, there is no clear prospect for a sustainable funding source, unless the central finance authority can provide funds in the future. To eliminate over-pumping, the measure should cover a larger area, which could contradict the country's grain security policy. The farmers' feedback and other challenges of the Seasonal Land Fallowing Program are described and discussed in more detail in Chap. 3.

\subsubsection{Substitution of Non-food Crops for Grain Crops}

Substitution of winter wheat by non-food crops was implemented mainly through subsidizing the planting of drought resistant tree species, with intercropping of forage grass, medicinal herbs, and other drought-tolerant crops instead of grain crops. Main tree species are fast growing poplar, Chinese ash, locust tree, and walnut tree. The 
subsidy standard is $1500 \mathrm{CNY} / \mathrm{mu}$ in the first year and $750 \mathrm{CNY} / \mathrm{mu} /$ year from the second to the fifth year (altogether $4500 \mathrm{CNY} / \mathrm{mu}$ in five years). Farmers do not need any more subsidy after the five-year period.

Replacing grain crops with trees can ideally save water for irrigation of winter crops, however the newly planted trees also need irrigation for the first few years before their roots have grown deep enough to completely rely on precipitation and deep soil water. Farmers can expect higher income through the subsidy in the first few years, but the income afterwards depends both on the market price of the trees and the management and technology for pest control. In some places it was reported that farmers planted fruit trees (for example pear trees), which in contradiction to the measure's purpose require intensive irrigation. Tree planting has been implemented in Handan and Guantao, but only on a very small scale. Its contribution to closing of the water gap is negligible up to now.

\subsubsection{Replacing Groundwater by Surface Water}

Since 2014 the Central Government has funded numerous engineering projects in all pilot prefectures in Hebei Province, involving dredging of river channels, renovation of the canal system and digging pits or ponds to improve the surface water supply system with storage facilities. All these measures aimed at increasing the fraction of the cropping area, which can be irrigated by surface water.

In Hebei Province, surface water is imported mainly through three projects, the SNWT, the Yellow River diversion and the Wei River diversion (Table 2.3). The surface water imported through the SNWT Project has so far been used to replace groundwater abstraction for households and industry in urban areas within the project's reach. In this way, over $80 \%$ of the urban groundwater abstraction has been eliminated by the end of 2020. Moreover, in areas with groundwater of high fluoride content and suitable local water supply networks, the imported surface water has been used to replace the extraction of deep confined groundwater and provide

Table 2.3 Effect of imported surface water on groundwater over-pumping control in 2014-2016

\begin{tabular}{l|l|l|l|l|l}
\hline Project & $\begin{array}{l}\text { Year of } \\
\text { implementation }\end{array}$ & $\begin{array}{l}\text { Imported } \\
\text { surface } \\
\text { water } \\
\left(\text { Mio. } \mathrm{m}^{3}\right)\end{array}$ & $\begin{array}{l}\text { Number of } \\
\text { wells closed } \\
\text { in } \\
\text { urban/rural } \\
\text { areas }\end{array}$ & $\begin{array}{l}\text { Groundwater } \\
\text { replaced in } \\
\text { rural areas } \\
\left(\text { Mio. } \mathrm{m}^{3}\right)\end{array}$ & $\begin{array}{l}\text { Affected } \\
\text { population/farmland } \\
\text { in rural area }\end{array}$ \\
\hline SNWT & $2014-2016$ & 511 & 4964 & 197 & 4.34 Mio. Capita \\
\hline $\begin{array}{l}\text { Yellow } \\
\text { River } \\
\text { diversion }\end{array}$ & $2014-2016$ & 784 & 6898 & 360 & 3.28 Mio. Mu \\
\hline $\begin{array}{l}\text { Wei River } \\
\text { diversion }\end{array}$ & $2014-2016$ & 157 & 1649 & 71 & 0.7 Mio. Mu \\
\hline
\end{tabular}


safe drinking water for 4.3 million people in 50 counties of Cangzhou, Hengshui, Xingtai, Handan and Langfang. The Yellow River diversion project and its water supply network could currently play a dual role of both importing and storing water, as a series of water storage projects such as canals, pools and ponds have been constructed simultaneously with the diversion works. From 2014 to 2016, in total 784 Mio. $\mathrm{m}^{3}$ of water from the Yellow River was transferred to Hebei and close to 7000 irrigation wells were shut down. The Wei River diversion project, which is traditionally supplying water for irrigation purposes, serves its task more efficiently through the updating of irrigation facilities in some small-scale irrigation districts. From 2014 to 2016, the actual amount of irrigation water applied increased by more than 150 Mio. $\mathrm{m}^{3}$ without increasing the total amount of imported water. In the same period, close to 1700 irrigation wells were shut down. According to the report of the pilot program "Comprehensive Control of Groundwater Overdraft in Hebei Province" (MWR/GIWP 2019), the imports of surface water contributed more than $40 \%$ of the total decrease of groundwater abstraction from 2014 till the end of 2018.

Through the import of surface water, groundwater overexploitation in urban areas of Hebei Province has been brought under control. In places where surface water is provided for irrigation, groundwater extraction in the agricultural sector has been significantly reduced. According to an assessment of the water import project conducted by a third party, from 2014 to 2016 the decline rate of groundwater levels in the pilot area has been decreasing under unchanged precipitation conditions (MWR/IHWR 2014). Ecological and environmental problems such as land subsidence and downward trend of the interface between saline water and fresh water in some areas have been alleviated. No further deterioration of the ecological environment has been observed.

The measure has an immediate and direct effect on saving groundwater and in addition increases net recharge through irrigation backflow. It also exhibits a high level of acceptance by farmers. The unit surface water price being lower than the pumping cost of the same amount of groundwater, they can cover their irrigation water needs at lower price.

However, the primary constraint is that surface water is insufficient, and supply is not reliable, neither spatially nor temporally. It often fails to arrive at the time of need. This was the reason why groundwater pumping had become so popular in the first place. The implementation of this measure mainly focused on the construction of canals, infiltration ponds, and pumping stations, while neglecting management including timing, which is the main prerequisite for distributing surface water efficiently. Although amounts imported to Guantao after 2014 look impressive (Table 2.4), their use has been extremely inefficient due to lacking infrastructure for distribution and storage. 
Table 2.4 Surface water imported to Handan and Guantao, including water for both domestic and agricultural use

\begin{tabular}{l|l|l}
\hline Year & $\begin{array}{l}\text { Surface water imported to Handan (Mio. } \\
\mathrm{m}^{3} \text { ) }\end{array}$ & $\begin{array}{l}\text { Surface water imported to Guantao (Mio. } \\
\mathrm{m}^{3} \text { ) }\end{array}$ \\
\hline 2014 & 643.25 & 31.87 \\
\hline 2015 & 689.54 & 36.00 \\
\hline 2016 & 658.32 & 36.00 \\
\hline 2017 & 794.22 & 39.00 \\
\hline 2018 & 852.14 & 43.00 \\
\hline 2019 & 800.00 & 59.00 \\
\hline 2020 & 862.41 & 43.10 \\
\hline
\end{tabular}

Source Handan General Management Office of Water Resources, Handan Water Resources Bulletin 2014-2020. Note that these figures contain surface water imported from both inside and outside the NCP. They cannot be compared to figures in Table 2.3. The Guantao figures were used in the modelling in Chap. 4

\subsubsection{Buy-Back of Water Rights}

Buyback of water rights was a measure promoted by the Ministry of Water Resources and tested in Cheng' an County in Handan Prefecture, starting in 2016. It integrated 10 villages in a monitoring platform. In 2017, the network was extended to over 70 villages. The ideal scheme for this system makes the water user association (WUA) buy back unused water rights from farmers at higher price, to subsequently sell them to other WUAs either through government or directly. The measure, which is illustrated in Fig. 2.1 was intended to enhance groundwater trading and establish a groundwater market. In reality, however, there was no WUA buying water from

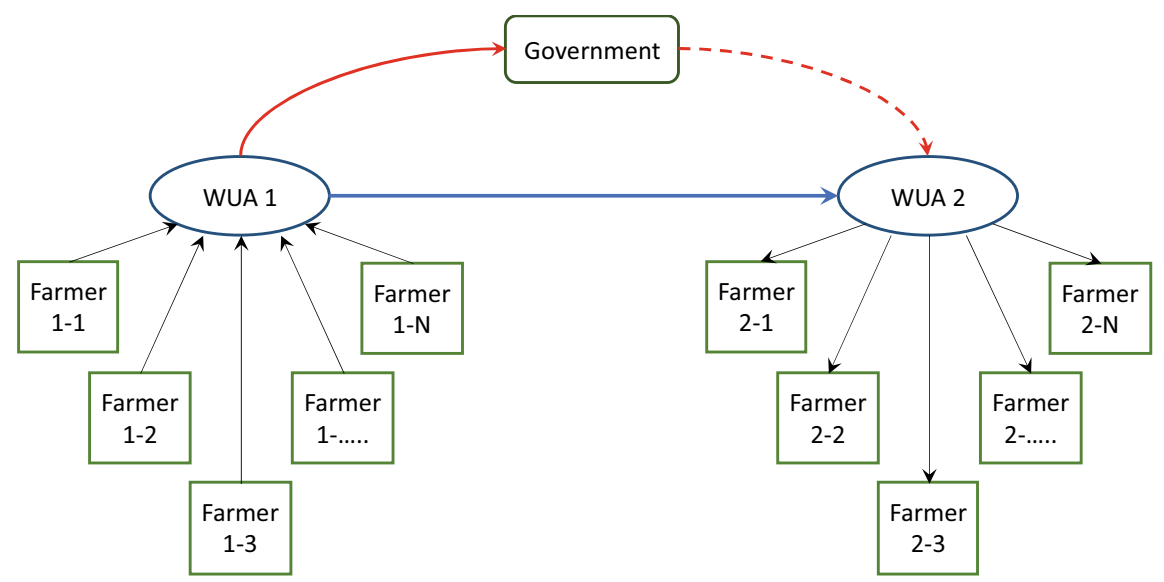

Fig. 2.1 Water right transfer model planned in Cheng'an 
another WUA. The government had to buy back the water rights at CNY 0.2 per $\mathrm{m}^{3}$. Farmers may trade informally among themselves, but they do not trade through the network in order to avoid the higher water price.

A positive outcome is that farmers' consciousness of water saving has been improved, once they got to know that saved water can be sold. Water sold to a WUA is not used as it is not traded to another WUA, which implies real water saving. Water trading, on the other hand, only increases water value. While it may incentivize individual farmers to save water on their own field, it will not reduce regional pumping as the traded water will also be used, only by users who can pay more.

The system in Cheng'an County had to be abandoned after a couple of years of trial due to lack of adequate and stable government repurchasing funds. Only 100,000 CNY available from the provincial government in 2016, were not enough to satisfy the sellers' demand in 2017, which was so high that government had to suspend the buy-back. A large number of informal water rights transactions exists within farm neighborhoods, who do not bother to go through the trouble of using the formal water rights market for the small amount of water rights they can trade. There is no highvalue-added agriculture or local industry water user who can buy additional water rights at higher price from the government. Such users, however, have proven to be an important prerequisite for a successful water market as established in Northwestern China.

\subsection{5 "Increase Price and Provide Subsidy"}

As part of the agricultural water pricing reform actions, "Increase price and provide subsidy" has been practiced in 14 counties in Hengshui prefecture, but not in Handan and the other two pilot prefectures. The mechanism of the reform measure is illustrated in Fig. 2.2. The water fee is charged to the farmers every month by their well managers by increasing the electricity price from 0.65 to $0.95 \mathrm{CNY} / \mathrm{kWh}$. The price increase of $0.30 \mathrm{CNY} / \mathrm{kWh}$ together with an additional subsidy of $0.15 \mathrm{CNY} / \mathrm{kWh}$ from local government is collected in an account managed by the Water User Association of the village. These funds are paid back to farmers according to their water saving performance twice a year in order to give an incentive for water saving while guaranteeing that farmers' income is not affected by the additional water fee.

The field research in one of the pilot districts in Hengshui, Taocheng District, showed that the local farmers' groundwater use for irrigating wheat and cotton decreased by $21 \%$ each. However, if no subsidies were granted, half of the region's farmers would lose money due to the increased electricity/water price. However, with the subsidy most farmers in the pilot villages were able to even earn some extra money (Wang et al. 2016). In another pilot site, Anping County, the scheme was less successful: 33 villages conducted the reform in 2017 and many of them abandoned the scheme in 2018. There was no obvious water-saving effect. The local government just wanted to accomplish the task given by the higher government level of making a reform, without the determination to have a real reform. 


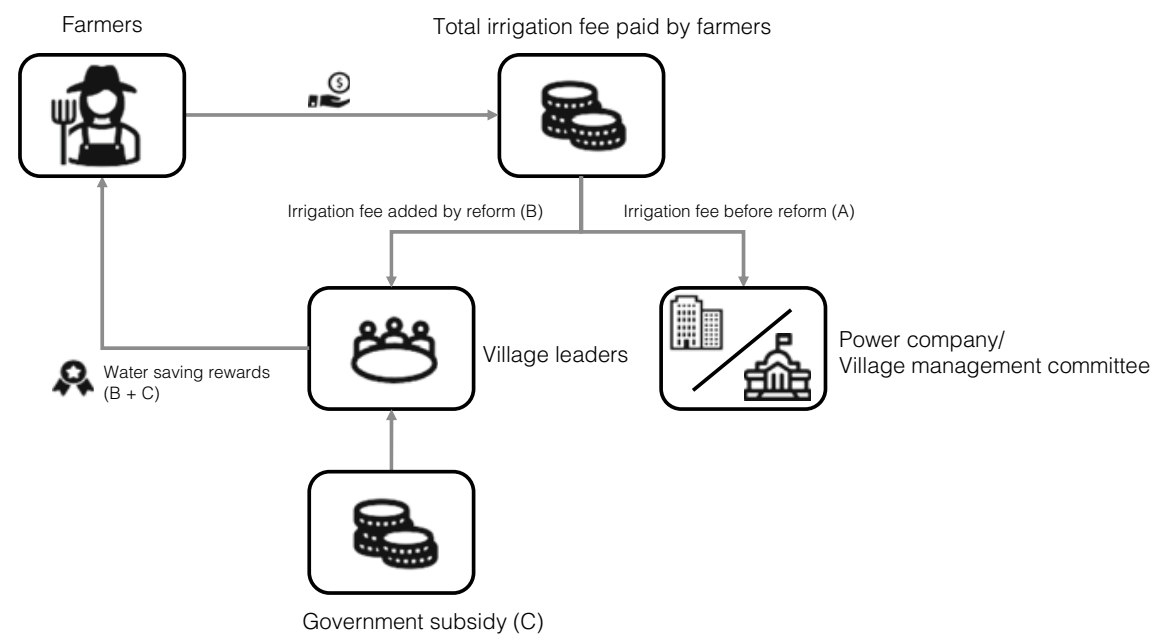

Fig. 2.2 Mechanism of "Increase Price and Provide Subsidy" pilot reform for groundwater irrigation in Taocheng District in Hebei Province

In the implementation process, the inclusion of the water fee in the electricity fee did not make the farmers feel that there is a fee for water. Regardless of the provincial government's request for inter-departmental cooperation, the electricity supplier was not willing to cooperate in the fee collection due to a conflict of interest. For them the scheme meant less sales of electricity and more administrative work. Due to the lack of a data sharing mechanism, the Department of Water Resources had to put considerable efforts into installing water meters and keeping water records, which induced heavy costs for the whole accounting process.

\subsubsection{Tiered Scheme of Water Fees}

The tiered scheme of water fees is also called the "Three lines and four ladder steps" method for determining the water fee (Fig. 2.3). The scheme is formulated, but calculation of water resources tax and fee according to use relies on installation of measurement facilities and metering. To meter millions of primitive irrigation wells in the NCP with smart water meters is almost an impossible task. It requires huge investments not only for the meters themselves but also for reconstructing wells and their piping and providing appropriate housing to protect the meters. In addition, such a system produces high maintenance cost. In 2017 Hebei Province adopted our suggestion for metering pumped volumes by proxy through electricity consumption. As every well has an electricity meter, this solved the difficulty of metering the large number of small, primitive wells. However, the fee collection could not be implemented up to now, neither in Guantao nor in any other pilot region in Hebei 


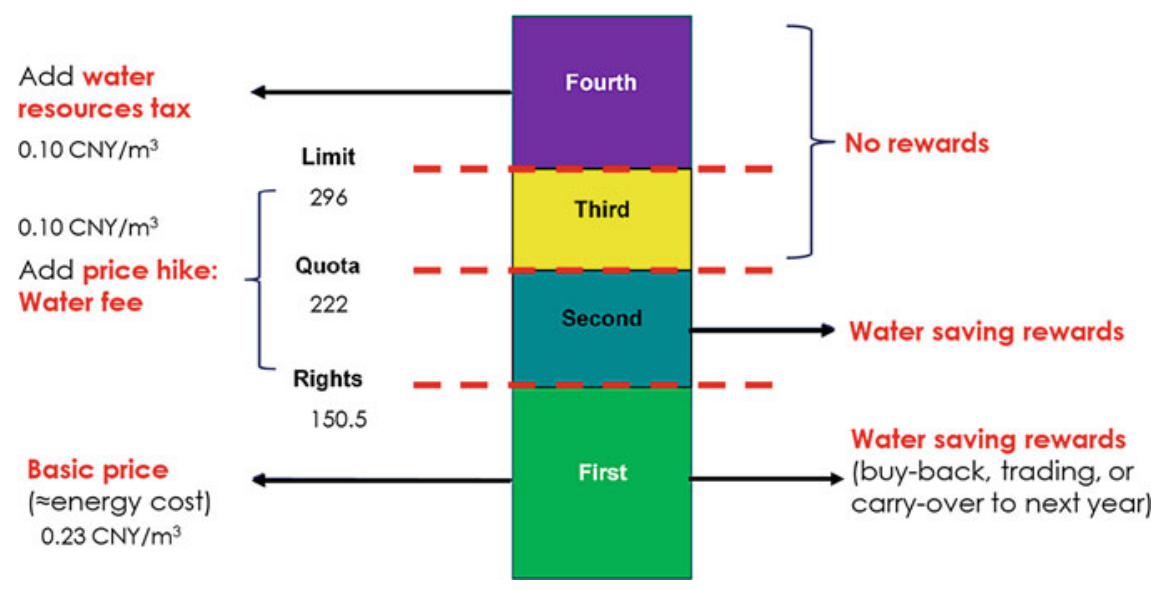

Fig. 2.3 Illustration of "Three lines and four ladder steps" fee collection system. The values of water limit, quota and rights are for Guantao

Province, due to the scheme's complex structure, the difficulty of collecting small amounts of money from millions of individual farmers and last not least the farmers' opposition to any fees.

The proposed agricultural water-pricing scheme is illustrated in Fig. 2.3. The basic price contains the electricity fee and an eventual management fee for the well manager. The water resources tax is $0.1 \mathrm{CNY} / \mathrm{m}^{3}$, the water fee for usage between water right and water limit (called price hike in the figure) is $0.1-0.2 \mathrm{CNY} / \mathrm{m}^{3}$, the water saving reward for grain crops staying below the quota is $0.2-0.3 \mathrm{CNY} / \mathrm{m}^{3}$. If a farmer stays even below the water right, he/she is eligible for a water saving reward e.g. in the form of buy-back at higher price or carry-over to the next season. There is not yet a unified standard among counties. The values of the three lines depend on the local hydrogeological situation and are expressed in units $\mathrm{of}^{3} / \mathrm{mu} / \mathrm{year}$. In Guantao the figures are $150.5 \mathrm{~m}^{3} / \mathrm{mu} / \mathrm{year}$ for the water right, $222 \mathrm{~m}^{3} / \mathrm{mu} / \mathrm{yr}$ for the quota and $296 \mathrm{~m}^{3} / \mathrm{mu} / \mathrm{year}$ for the limit. The difference between a fee and a tax is where it ends up: The fee stays in the county while the tax goes into the state treasury.

Unlike the situation in Hengshui, Guantao Department of Water Resources managed to establish a close and friendly cooperation with the Electricity and Power Supply Company (EPSC) of Guantao. Electricity data were shared for the calculation of pumped volumes. The data includes monthly data of each district and yearly data of each irrigation well. Together with the conversion factors described in Chap. 4, this enabled us for the first time to estimate with good accuracy how much groundwater was pumped in each district and well.

The tax scheme is based on water use per area. In principle, it is possible to calculate the pumped groundwater volume per unit area for each village and each family from the land area and the electricity consumption recorded by village electricians and well managers. It is not possible to do so with the easily accessible electricity data for each well, as the area irrigated by a well can change considerably with the 
season and from year to year. The flexibility is made possible by the underground piping infrastructure created since the World-Bank-financed GEF project.

DWR is responsible for calculating each well's specific water use. Since 2017, they report every well surpassing the limit to the tax department, which in turn is responsible for collecting the tax. Although water tax has been due for a number of wells, the tax department did not collect the tax, the amount generated in the irrigation sector being minor compared to the cost of organizing the tax collection. Water tax has, however, been collected from industrial users since 2016.

Water fees for wells surpassing the quota have been calculated by DWR, but fees were not collected due to farmers' opposition. Moreover, present fees for water use above the quota are too low to make an impact. On average, no township exceeds the limit of $294 \mathrm{~m}^{3} / \mathrm{mu} /$ year relevant for taxing. Average water use of the county as a whole does not exceed the quota of $222 \mathrm{~m}^{3} / \mathrm{mu} /$ year. In townships with exceedance of the quota, the amounts are between 20 and $50 \mathrm{~m}^{3} / \mathrm{mu} /$ year, the fee for which would amount to insignificant 2-5 CNY/mu/yr. Only greenhouse farmers will have higher water fees, which they, however, can easily pay due to higher profits from their cultures. It has been suggested that present fees should be low to introduce the system smoothly. Once it is in place, fees can be increased. Only if fees lead to water saving, they are justified. If they have no effect on water use, they should either be increased to a level inducing water saving or be abandoned.

The option of automatic smart water metering was tried out in an experiment, collecting the water fee directly via smart cards, but the investment and maintenance costs were both exceedingly high compared to the fees collected. Most meters were broken within a couple of years of installation.

The fee according to the current scheme can only be calculated at the end of the irrigation season, involving all surface and groundwater use. By that time, mistakes of the past season can no longer be corrected. A price solution may have an immediate effect on farmers' irrigation practice. In addition, a price solution does not require the knowledge of the area irrigated by each well. We therefore proposed a direct collection of water fees together with and proportional to the electricity fees. This would make an extra collection system for water fees obsolete. Up to now, Guantao EPSC is not willing to provide this service. The water fee collection system has promoted the consciousness among farmers that water is a valuable resource, but lacking the implementation in practice, it does not unfold its potential to promote water saving.

When choosing the water price solution, the water price (added to present electricity cost) should be at a level equal to farmers' marginal earnings from agricultural production. For example, if marginal earnings in planting wheat amount to 100 $\mathrm{CNY} / \mathrm{mu}$ and $160 \mathrm{~m}^{3} / \mathrm{mu} /$ year are required for irrigation that means the water price should be at least $0.6 \mathrm{CNY} / \mathrm{m}^{3}$. At that level, farmers on the margin would abandon wheat planting. 


\subsubsection{Import of Surface Water Versus Water Saving and Change of Cropping Structure}

In 2019 the State Council approved the "Integrated action plan for groundwater overdraft control in North China Plain" (or in short form: Action Plan 2019). This plan lists 18 main control actions grouped in four categories of instruments. It is hoped that these allow to reach the target of reducing annual groundwater exploitation by 2.57 Bio. $\mathrm{m}^{3} /$ year (or about $70 \%$ of the remaining annual groundwater over-exploitation) in Beijing, Tianjin, and Hebei (BTH) region by 2022. Note that in this action plan the already existing annual surface water imports to BTH region are not included. In 2018 they reached a total of $4.5 \mathrm{Bio} . \mathrm{m}^{3} /$ year, basically eliminating the over-pumping in Beijing and Tianjin.

The Action Plan 2019 lists the measures to be implemented in BTH region by 2022 to further reduce groundwater pumping. They include water saving, change in cropping structure, and replacement of groundwater by surface water imported from the SNWT, the Yellow River and other local water resources. The targeted reductions of groundwater pumping each measure can achieve are listed in Table 2.5. The long-term goal is to eliminate over-pumping completely by 2035 .

The main measures recommended in the Action Plan 2019 are the ones, which have proven to be effective in the pilot projects. Figure 2.4 lists the implementation progress in 2019 in terms of the main measures of the Action Plan 2019. To appreciate the tasks, a few comments are helpful. A reduction of pumping by 0.24 Bio. $\mathrm{m}^{3}$ /year through water saving measures on 4.17 Mio. mu of farmland is ambitious. It averages to a saving of $57.6 \mathrm{~m}^{3} / \mathrm{mu} / \mathrm{year}$, which is equivalent to the amount of a single irrigation event and probably overestimates the water saving capacity for grain crops. For greenhouses, savings of this order of magnitude are feasible through drip irrigation. Cropping structure change is mainly implemented through winter wheat fallowing and could save $0.60 \mathrm{Bio} . \mathrm{m}^{3} /$ year through fallowing of $4.85 \mathrm{Mio}$. mu (or 0.32 Mio. ha) by 2022 . This amounts to $13.6 \%$ of the wheat planting area of Hebei (2.36 Mio. ha in 2018 according to China's Statistical Yearbook) and might be difficult to achieve. Importing surface water seems less difficult to accomplish. Using it to replace groundwater in irrigation still poses problems: The farmland infrastructure, which is mainly based on groundwater irrigation, is not yet capable to receive such large amounts of surface water. The canal system is insufficient as are storage facilities, which would allow to match the timing of surface water imports to the irrigation calendar. This is also the reason why a large percentage of surface water imports accomplished by the end of 2019 (3.49 Bio. $\mathrm{m}^{3}$ out of 8 Bio. $\mathrm{m}^{3}$ shown in Fig. 2.4) could only be used for artificial groundwater recharge through rivers and lakes. Note that the progress in the first two measures shown in Fig. 2.4 is expressed in area equipped. While the bars for the accomplished task look longer for water saving than for change of cropping structure, the corresponding amounts of water saved are clearly larger for the second item.

The groundwater saving capacity added through the newly implemented measures in BTH area in 2019 is shown in Fig. 2.5. In total, only an additional 0.67 Bio. $\mathrm{m}^{3}$ of 


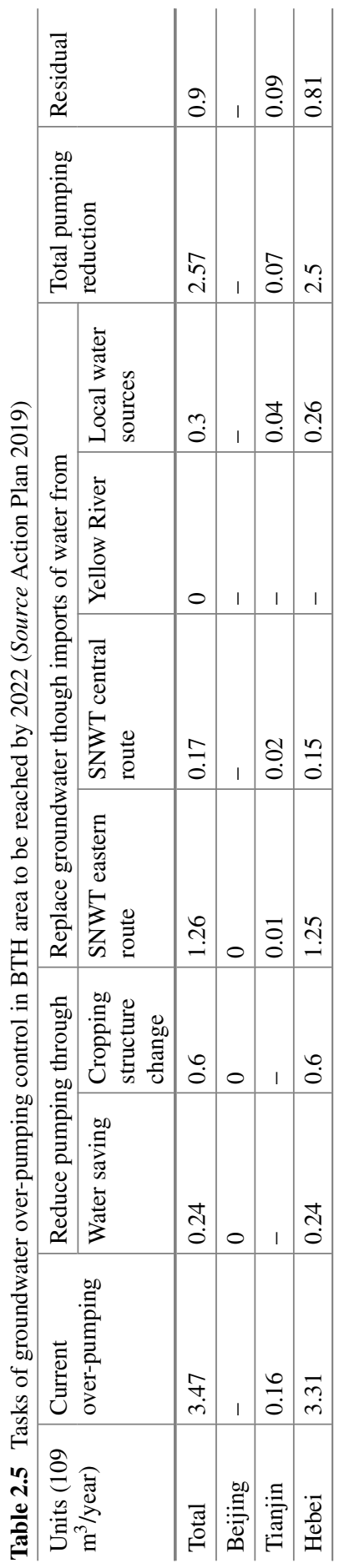




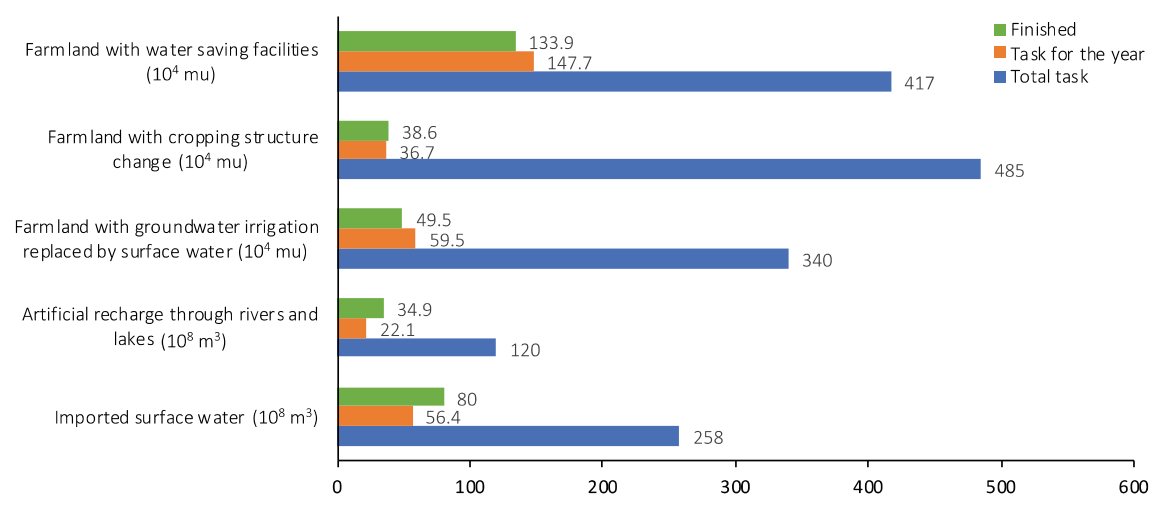

Fig. 2.4 Main measures listed in Action Plan 2019 for BTH area: Implementation progress of year 2019, in comparison to task figures for 2019 as well as the whole implementation period until 2022. Data source: (MWR GIWP and Hai River Comission 2020)

Fig. 2.5 Groundwater saving achieved by different measures in 2019 (Units: $10^{8}$ $\mathrm{m}^{3}$ ). Source (MWR GIWP and Hai River commission 2020)

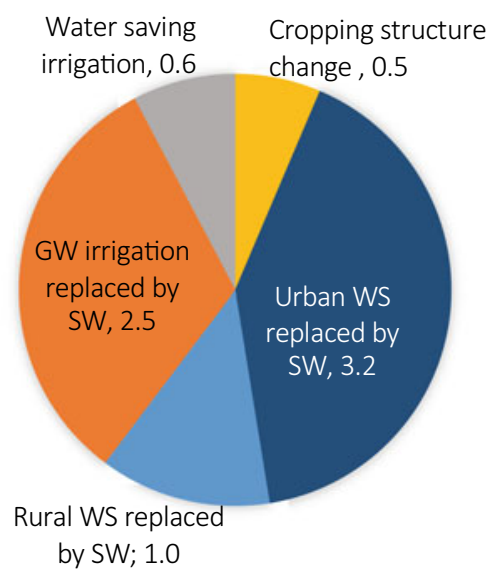

imported surface water could be used to replace groundwater pumping in comparison to a total amount of 5.6 Bio. $\mathrm{m}^{3}$ imported to the region. Within this small replacement, more than $60 \%$ was used to replace groundwater supply for domestic use in both rural and urban regions. Replacing groundwater by surface water in irrigation contributed less than one third to the total increase in groundwater saving for the year. Out of 250 Mio. $\mathrm{m}^{3}$ only 70 Mio. $\mathrm{m}^{3}$ was diverted to the newly equipped farmland $\left(495^{\prime} 000\right.$ $\mathrm{mu}$ ), while the rest was diverted to farmland, which had already been equipped with surface water irrigation infrastructure before 2019, but never received water.

Cropping structure change (mainly through fallowing of winter wheat) contributed about 50 Mio. $\mathrm{m}^{3}$ of groundwater saving, water saving irrigation another 60 Mio. $\mathrm{m}^{3}$. Both measures seem to contribute little, but in comparison to the real increase of surface water irrigation capacity $\left(70 \mathrm{Mio} . \mathrm{m}^{3}\right)$, all three measures are important in achieving the goal of reducing groundwater pumping, especially when considering 
that farmland with surface water irrigation capacity might still use groundwater when surface water does not arrive on time. Increasing the efficiency of surface water use in replacing groundwater in irrigation should be the main focus in the future.

In 2019 the actual amount of surface water imported to the BTH region was 8 Bio. $\mathrm{m}^{3}$ in total. More than $40 \%$ were used for artificial recharge in rivers and lakes to promote ecological rehabilitation, in exceedance of planned figures, as the ability of agricultural land to receive surface water for irrigation was too small. In this situation, MAR is a convenient way of making use of excess surface water not used for irrigation. Two examples are shown here.

In Guantao County, two infiltration basins were built (Fig. 2.6). They were filled once or twice a year with off-season surface water from the Yellow River. Seepage conditions were not ideal in Guantao's rather clayey soils. Still, according to our measurements they allowed about half of the applied water to infiltrate, while the other half evaporated (Mérillat 2016). The volume of a full basin of 35,900 $\mathrm{m}^{2}$ area was $110,000 \mathrm{~m}^{3}$ per filling. Such ponds can at the same time serve as short term water storage, holding surface water until it is needed, to increase the efficiency of its utilization.

Better results were achieved by discharging excess water from the SNWT into some of Hebei's dry riverbeds, leading to a significant groundwater table rise along the river courses. One example is shown in Fig. 2.7. Water from the SNWT was diverted into the bed of the usually dry Fuyang River in Hebei via a weir in the location, where the Central Route of the SNWT crosses the river. The observation wells in the vicinity of the river showed a rise of the groundwater table of $0.5 \mathrm{~m}$ to more than $5 \mathrm{~m}$. Infiltration of South-North water in the outskirts of Beijing has also been successful in raising groundwater levels (Long et al. 2020). Of course, due
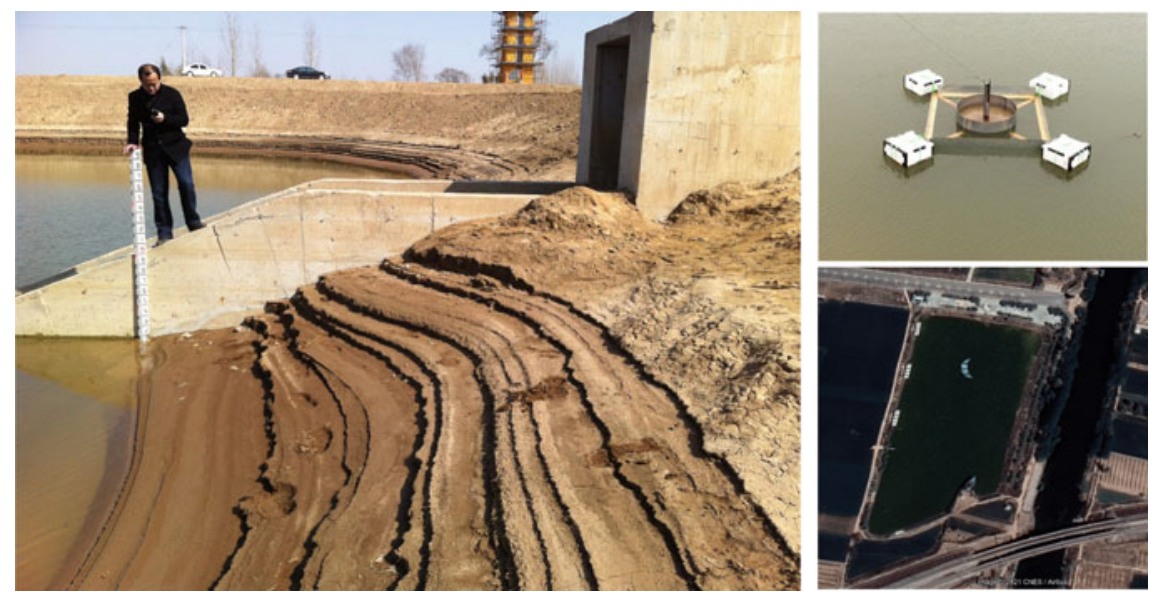

Fig. 2.6 Infiltration basin in Guantao County with water depth gauge (left) and floating evaporation pan (upper right) to measure evaporative losses. A satellite image (bottom right) shows the extent of the infiltration pond, which is called "Moon Lake" 


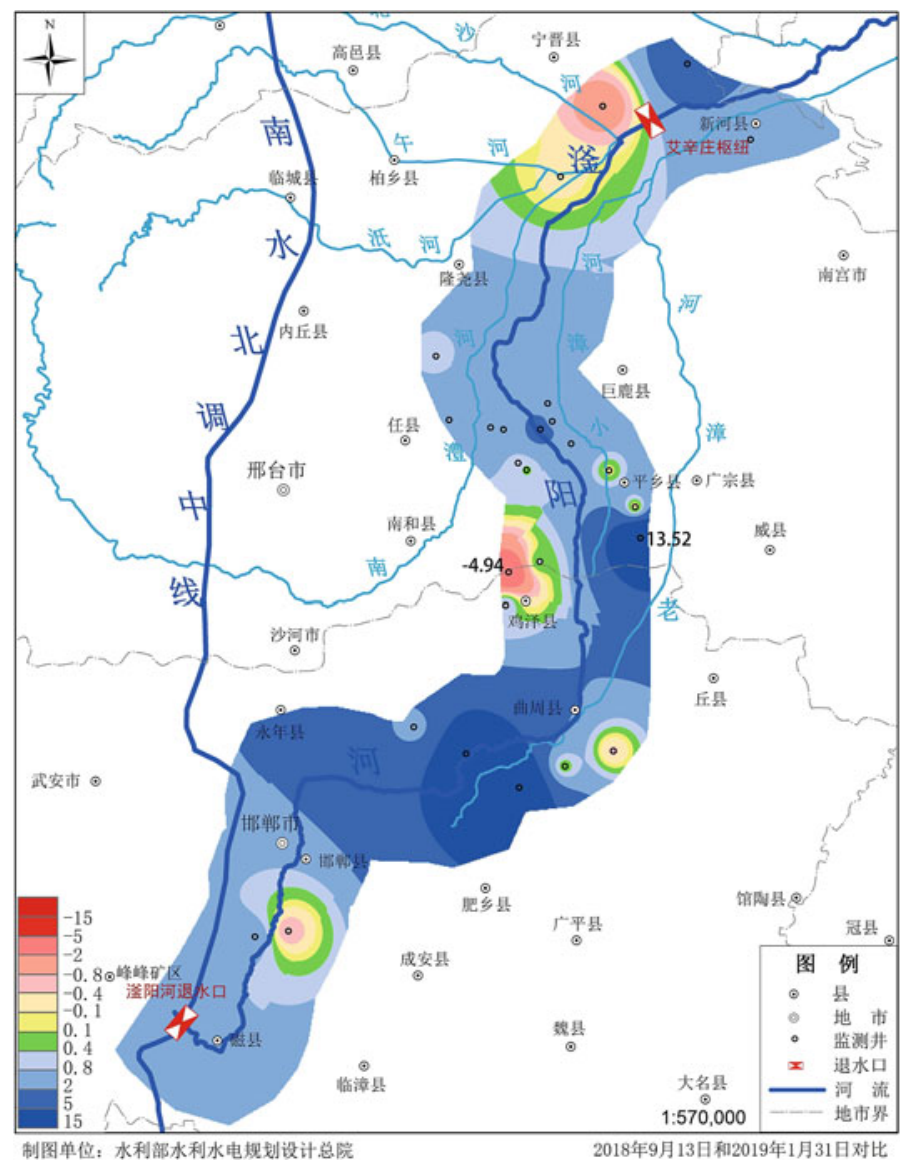

Fig. 2.7 Infiltration in river bed: Example Fuyang River, Hebei. Reaction of groundwater table to water release from South-North Transfer Central Route. Three blue tones in increasing intensity: water table rise, up to 2, 5 and $15 \mathrm{~m}$. Source MWR GIWP (2019)

to the high cost of water imports, their use for MAR can only be the option of last resort.

Using surface water for irrigation saves the energy required for pumping groundwater and allows to rehabilitate not only land adjacent to lakes and rivers, but areas in larger need, such as the most severe overdraft zones. In addition, it contributes to groundwater recharge by irrigation backflow. Improving conjunctive allocation of various water resources for the region should be the focus in the coming years to make sure the imported surface water replaces groundwater in irrigation to its maximum potential. 


\subsection{Governance Structure in the Water Sector}

Water governance comprises all processes of governing the supply and use of water by relevant institutions throughout society by means of laws, norms, and regulations. As everywhere in the world, it is a multi-stakeholder affair in China. There are three main institutional systems involved: The Ministry of Water Resources with its substructures on provincial and county levels, the Ministry of Agriculture and Rural Affairs with similar substructures and the State Grid Corporation of China with its branches on provincial and county level. Another but lesser player is the Ministry of Natural Resources, whose competences are mainly in groundwater monitoring and resource capacity assessment rather than groundwater governance. The Ministry of Agriculture and Rural Affairs is the national agricultural policy maker, and no agricultural measures can be taken without its consent. Agriculture as the main water user is responsible for $60-80 \%$ of total groundwater pumping in the NCP. With the cropping structure governed through its subsidies, the Ministry of Agriculture has the largest influence on limiting over-pumping. At the same time, it has the-conflictingnational task of upholding food security. The Ministry of Water Resources has the decisive power in supplying water infrastructure and diverting surface waters, which explains their preferred strategy of water transfers. The electric power utilities as the power supplier for pumping have a very comprehensive and fully functional metering and fee collection network for electricity consumption. Since the electricity suppliers certainly opt for selling as much electric energy as possible, pumping control in principle harms their interest. Involving electricity suppliers is crucial in designing pumping metering, fee collection and control strategies for groundwater usage.

The ideal case would be a smooth cooperation among the three governing structures serving the farmers as private stakeholders, who in the end will have to cooperate in the implementation of policies. In practice, the existing cooperation is often hampered by the struggle for competences, power, and funds among the three governing structures. While all governance in China seems top-down, it cannot ignore the wishes of the governed, in this case the farmers, who can render any policy ineffective by refusing to cooperate.

\subsubsection{Governmental Stakeholders in Water Sector}

On the central government level, Ministry of Water Resources and Ministry of Agriculture and Rural Affairs are both working under the State Council. Departments of Water Resources and Agriculture and Rural Affairs are governmental bodies, which receive administrative orders from the local government (provincial, prefecture and county levels), and technical instructions from their respective ministries, as shown in Fig. 2.8. The heads of departments are normally employed by the local governments, while the technical staff working in different departments are hired through 


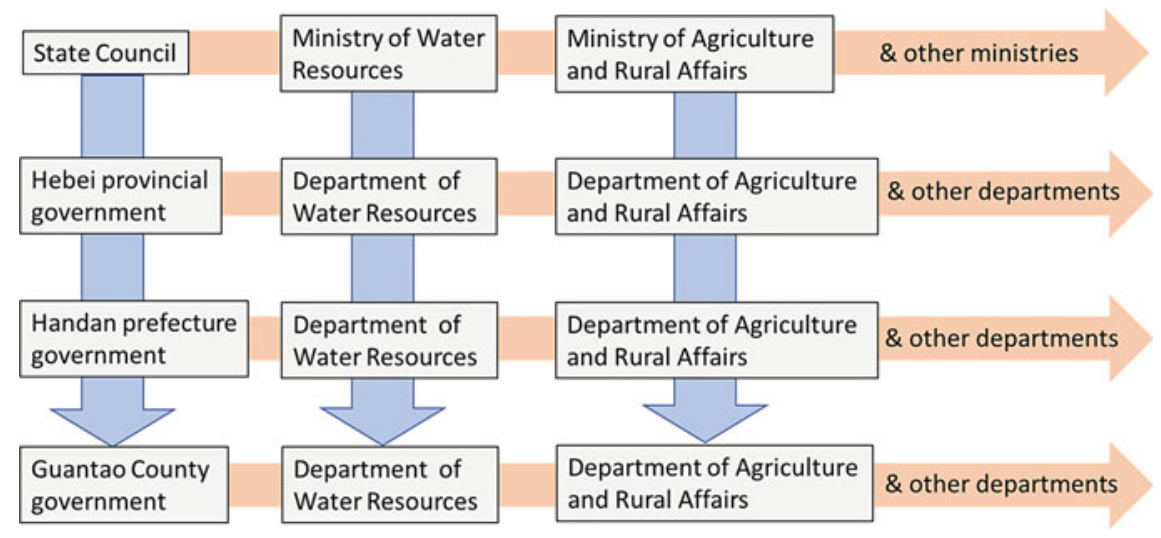

Fig. 2.8 Illustration of matrix structure of governmental administration in China involved in groundwater over-pumping control in Guantao County

government funds, or partially through project funds procured either from the local governments or from ministries.

The program "Integrated Pilot Planning for Governing Groundwater Overdraft" was initiated by the central government in Beijing with funds given to Hebei Province directly. Four prefectures in Hebei Province (including Handan) were chosen as pilot sites, different departments on prefecture level took up the task to implement the measures and distribute the work among their respective county level departments. The ministries involved supported the national initiative of over-pumping control by providing planning guidelines and recommending and promoting various measures.

\subsubsection{Stakeholders in the Electricity Sector Related to Irrigation}

In China electricity supply and its distribution network belonged to the State Power Corporation of China, a state enterprise founded in 1997 and dismantled in 2002 due to the institutional reform of the electric power sector. Since then, the power supply grid in the NCP belongs to the State Grid Corporation of China, a state-owned enterprise. The company has sub-branches in Hebei Province, Handan Prefecture and Guantao County.

In Guantao County, electric energy is supplied and managed by Guantao Electric Power Supply Company (EPSC), which is affiliated with the State Grid Corporation of China. Its organizational and electricity metering systems are shown in Fig. 2.9.

The EPSC is in charge of eleven Electric Power Supply Agencies (EPSA) at district level. Each EPSA manages the electric power supply of about twenty villages. In each village, one or two electricians employed by EPSA are responsible for power infrastructure maintenance. The village electricians are also responsible for collecting 


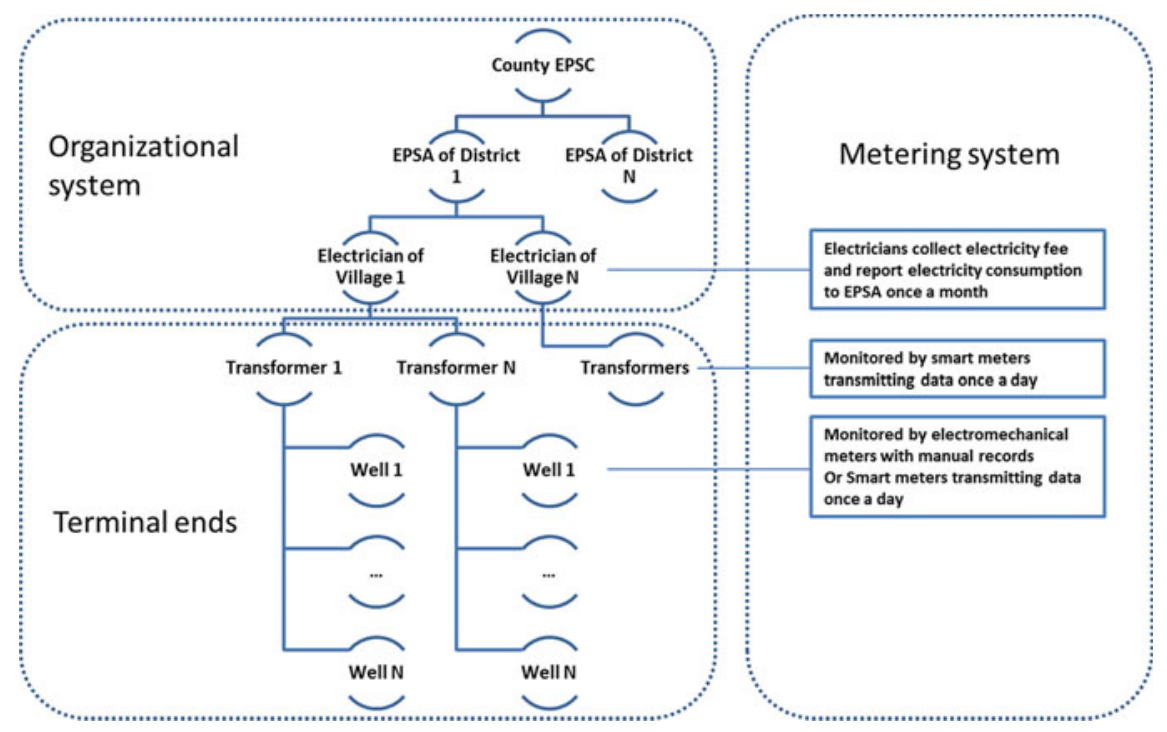

Fig. 2.9 Organizational system and terminal ends of the electric power distribution system (left boxes) and the metering system (right box)

electricity fees from the end users. In the case of irrigation, the end-users are the well managers who are owners of a well or take care of a well, owned by several households. For a well shared by several farmers, a written chronological log of pump operations is kept, recording the readings of the electricity meter when the pump is turned on and off. The electricity fees are collected by the well manager on a monthly basis, according to the energy consumption records of individual farmers. Based on the existing electricity metering system, groundwater pumping can be monitored at different levels. Since 2018, all wells are equipped with smart electricity meters, which transmit daily electricity consumption to the utility.

\subsubsection{Stakeholders in the Water Sector of Guantao County}

The Department of Water Resources in Guantao County is the main governmental stakeholder playing a major role in the pilot program for over-pumping control. It is responsible for implementing the engineering measures of replacing groundwater by importing surface water, through construction of canals, infiltration ponds, and surface water pumping stations. The department is also responsible for promoting water saving by providing subsidies for water saving irrigation equipment and carrying out the agricultural water pricing reform. 
On one hand, the Department of Water Resources in Guantao made a huge effort to set up metering and fee collection for imported surface water. However, for groundwater pumping control, which involves individual farm households, they have to rely on the village administration. In 2007, a World Bank project tried to set up Water User Associations (WUA) in each village. Due to China's strict control of the number of non-governmental organizations within a county, eventually a WUA was set up in Guantao as one organization for the whole county, each village's WUA being a sub-branch of it. The village WUA therefore normally only comprises the village leaders and part of the village administration, receiving governmental orders instead of being the bottom-up initiative, as which it is known outside of China.

In recent years after our strong recommendation and also due to the fact that groundwater pumping has to be metered through pumping electricity, most of the villages have integrated the village electricians as members into the WUAs. As contract employees of Guantao EPSC, village electricians are paid to collect electricity fees from well managers, who themselves receive an additional irrigation service fee from the well users according to the amount of pumping. The governmentally organized WUAs, however, exist in name only. They do not receive any funding, neither from villagers nor from the government. Therefore, their possibly very useful function in collecting water fees cannot be realized so far.

\section{References}

Calow RC, Howarth SE, Wang J (2009) Irrigation development and water rights reform in China. Int J Water Resour Dev 25(2):227-248. https://doi.org/10.1080/07900620902868653

Debaere P, Richter B, Davis K, Duvall M, Gephart, J, O’Bannon, et al. (2014). Water markets as a response to scarcity. Water Policy 16(4):625-649.https://doi.org/10.2166/wp.2014.165

Etchells T, Malano H, McMahon T (2006) Overcoming third party effects from water trading in the Murray-Darling Basin. Water Policy 8:69-80. https://doi.org/10.2166/wp.2006.0005

Frija A, Dhehibi B, Chebil A, Villholth KG (2015) Performance evaluation of groundwater management instruments: The case of irrigation sector in Tunisia. Groundw Sustain Dev 1:23-32. https:// doi.org/10.1016/j.gsd.2015.12.001

Heaney A, Hafi A, Beare S, Wang J (2005) Water reallocation in Northern China: towards moreformal markets for water. In: Willet IR, Gao Z (eds) Agricultural water management in China. Australian Center for International Agricultural Research, pp 130-141

Howe C, Schurmeier D, Shaw W (1986) Innovative approaches to water allocation: the potential for water markets. Water Resour Res 22(4):439-445. https://doi.org/10.1029/WR022i004p00439

Huang Q, Wang J, Rozelle S, Polasky S, Liu Y (2013) The effects of well management and the nature of the aquifer on groundwater resources. Am J Agr Econ 95(1):94-116. https://doi.org/ 10.1093/ajae/aas076

Johansson R, Tsur Y, Roe T, Doukkali R, Dinar A (2002) Pricing irrigation water: a review of theory and practice. Water Policy 4:173-199. https://doi.org/10.1016/S1366-7017(02)00026-0

Kemper KE (2007) Instruments and institutions for groundwater management. In: Giordano M, Villholth KG (eds) The agricultural groundwater revolution: opportunities and threats to development. CABI, Wallingford, pp 153-172

Lewis D, Zheng H (2018) How could water markets like Australia's work in China? Int J Water Resour Manag 34(3):1-21. https://doi.org/10.1080/07900627.2018.1457514 
Long D, Yang W, Scanlon BR, Zhao J, Liu D, Burek P, Pan Y, You L, Wada Y (2020) South-to-North Water Diversion stabilizing Beijing's groundwater levels. Nat Commun 11:3665https://doi.org/ 10.1038/s41467-020-17428-6

Mérillat A (2016). Estimation of the infiltration rate from an artificial lake in Guantao County, China. Master thesis, Institute of Environmental Engineering, ETH Zurich.

Moore S (2015). The development of water markets in China: progress, peril, and prospects. Water Policy, 17(2). https://doi.org/10.2166/wp.2014.063

MWR (2010). Technical Code for Water Wells. Published by Ministry of Housing and Urban-Rural Development and State Administration for Quality Supervision and Inspection and Quarantine.

MWR/IWHR (2014). The third-party evaluation report on the pilot project of comprehensive groundwater overexploitation control in Hebei Province. Report of IWHR (in Chinese).

MWR/GIWP (2019). Comprehensive Control of Groundwater Overdraft in Hebei Province. Report of GIWP (in Chinese).

MWR GIWP (2019). Final evaluation report on pilot project of artificial recharge through rivers and lakes of integrated action plan for groundwater overdraft control in North China Plain. Report of the GIWP (in Chinese).

MWR GIWP and Hai River Commission (2020). The summary and evaluation report of integrated action plan for groundwater overdraft control in North China Plain in 2019. Report of the GIWP (in Chinese).

Shen D (2015) Groundwater management in China. Water Policy 17:61-82. https://doi.org/10.2166/ wp.2014.135

Speed R (2009) A comparison of water rights systems in China and Australia. Int J Water Resour Dev 25(2):389-405. https://doi.org/10.1080/07900620902868901

State Council (2012). Opinions on the implementation of the strictest water resources management system. Retrieved from http://www.gov.cn/zwgk/2012-02/16/content_2067664.htm

Sun T, Wang J, Huang Q, Li Y (2016) Assessment of water rights and irrigation pricing reforms in Heihe River Basin in China. Water 8(3338). https://doi.org/10.3390/w8080333

Wang J, Zhang L, Huang J (2016) How could we realize a win-win strategy on irrigation price policy? Evaluation of a pilot reform project in Hebei Province, China. J Hydrol 539:379-391. https://doi.org/10.1016/j.jhydrol.2016.05.036

Wang J, Li Y, Huang J, Yan T, Sun T (2017) Growing water scarcity, food security and government responses in China. Glob Food Secur - Agric Policy Environ 14:9-17. https://doi.org/10.1016/j. gfs.2017.01.003

Wang J, Jiang Y, Wang H, Huang Q, Deng H (2020) Groundwater irrigation and management in northern China: status, trends, and challenges. Int J Water Resour Dev 36(4):670-696. https:// doi.org/10.1080/07900627.2019.1584094

Wang J, Zhu Y, Sun T, Huang J, Zhang L, Guan B, Huang Q (2020) Forty years of irrigation development and reform in China. Aust J Agric Resour Econ 64(1):126-149. https://doi.org/10. 1111/1467-8489.12334

Yu X, Geng Y, Heck P, Xue B (2015) A review of China's water management. Sustainability 7:5773-5792. https://doi.org/10.3390/su7055773 
Open Access This chapter is licensed under the terms of the Creative Commons Attribution 4.0 International License (http://creativecommons.org/licenses/by/4.0/), which permits use, sharing, adaptation, distribution and reproduction in any medium or format, as long as you give appropriate credit to the original author(s) and the source, provide a link to the Creative Commons license and indicate if changes were made.

The images or other third party material in this chapter are included in the chapter's Creative Commons license, unless indicated otherwise in a credit line to the material. If material is not included in the chapter's Creative Commons license and your intended use is not permitted by statutory regulation or exceeds the permitted use, you will need to obtain permission directly from the copyright holder.

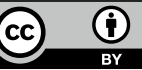

